\title{
Functional comparison of anoctamin 1 antagonists on human uterine smooth muscle contractility and excitability
}

\author{
Shunsuke HYUGA ${ }^{1}$, Jennifer DANIELSSON ${ }^{1}$, Joy VINK ${ }^{2}$, Xiao Wen FU ${ }^{1}$, \\ Ronald WAPNER ${ }^{2}$ and George GALLOS ${ }^{1}$ \\ ${ }^{1}$ Department of Anesthesiology, Columbia University College of Physicians and Surgeons, \\ Columbia University Medical Center, New York, NY \\ ${ }^{2}$ Department of Obstetrics \& Gynecology, Columbia University College of Physicians and \\ Surgeons, Columbia University Medical Center, New York, NY
}

Submitted April 20, 2018; accepted in final from May 26, 2018

\begin{abstract}
Background: Pre-term birth is a major health care challenge throughout the world, and preterm labor represents a potentially reversible component of this problem. Current tocolytics do not improve preterm labor beyond $48 \mathrm{~h}$. We have previously shown that anoctamin 1 (ANO1) channel blockade results in relaxation of pre-contracted human uterine smooth muscle (USM). Three drug classes with reported medicinal effects in humans also have members with ANO1 antagonism. In this study, we compared the ability of representatives from these 3 classes to reduce human USM contractility and excitability. Objective: This study sought to examine the comparative potency of 3 ANO1 antagonists on pregnant human USM relaxation, contraction frequency reduction, inhibition of intracellular calcium release and membrane hyperpolarization. Methods: Experiments were performed using: 1) Ex vivo organ bath (human pregnant tissue), 2) Oxytocin-induced calcium flux (in vitro human USM cells) and 3) Membrane potential assay (in vitro human USM cells). Results: Benzbromarone (BB) demonstrated the greatest potency among the compounds tested with respect to force, frequency inhibition, reducing calcium elevation and depolarizing membrane potential. Conclusion: While all 3 ANO1 antagonists attenuate pregnant human uterine tissue contractility and excitability, BB is the most potent tocolytic drug. Our findings may serve as a foundation for future structure-function analyses for novel tocolytic drug development.
\end{abstract}

Key words: ANO1, preterm labor, tocolytic

Corresponding author: George Gallos, MD, Department of Anesthesiology, Columbia University College of Physicians and Surgeons, 622 W. 168th St. P\&S Box 46, New York, New York 10032, USA

Phone: +1-212-342-4799 e-mail: gg2125@cumc.columbia.edu

(C2018 The Japan Society of Smooth Muscle Research 


\section{Introduction}

Pre-term labor (PTL) is a major contributor to spontaneous premature birth, a condition associated with high maternal and fetal morbidity $(1,2)$. Although the etiology of PTL is varied, the common endpoint between all causes remains the initiation and maintenance of forceful and rhythmic uterine smooth muscle (USM) contractions (3). While progesterone therapy holds promise as a prophylactic treatment for certain subgroups of patients with history of pre-term birth (4), the mainstay of treatment for established PTL remains tocolysis $(5,6)$. Unfortunately, conventional tocolytics have been plagued by side effects and a lack of sustained efficacy beyond $48 \mathrm{~h}$ of use (6). Therefore, identification of novel tocolytic strategies is necessary to address this global health concern.

One potential tocolytic target is the calcium-activated chloride channel (CaCC) family member anoctamin 1 (ANO1). CaCC currents have long been recognized as important modulators of smooth muscle excitability (7-9). These channels are voltage-gated and responsive to elevations in intracellular calcium levels, making them uniquely suited to participate in excito-mechanical coupling and action potential (AP) generation in smooth muscle tissues $(7,10)$. The relationship between frequency, amplitude, and duration of USM contractions has long been associated with the frequency of AP bursts and the duration (plateau) of these bursts, respectively (11). With regard to exito-mechanical coupling, Jones et al. demonstrated that CaCC are activated by calcium entry via voltage-gated calcium channels (VGCC), highlighting a relationship between CaCC and VGCC in both spontaneous and oxytocin-stimulated contractions in myometrium (7). In the USM cell, CaCC activation leads to an enhanced outward chloride current to further depolarize the uterine smooth muscle cell membrane and thereby increase excitability. In this context, $\mathrm{CaCC}$ channel-mediated depolarization may assist in further VGCC's (L-type) activation for enhancing AP generation. In addition, some evidence suggests that $\mathrm{CaCC}$ may also participate in both stabilizing plateau potentials as well as influencing electrical spike frequency (12). Furthermore, others have shown increases in $\mathrm{CaCC}$ flux following oxytocin stimulation of the rat uterus, highlighting its association with labor-induced hormonal fluctuations (13). While the role of $\mathrm{CaCC}$ in myometrial contractility has been established as important, these studies have largely been limited to rodent models (7, 14-16) and did not examine a specific molecular target.

Molecular identification of the ANO1 channel as a CaCC was not established until recently (17-19). The ANO1 channel is now known to play important roles in various cell types including airway and intestinal epithelial cells, smooth muscle cells, intestinal pacemaker cells, and sensory neurons (20-23). Our group has previously reported on the functional expression of the ANO family (TMEM16) in both airway and uterine smooth muscle $(24,25)$. In USM we have shown that ANO1 antagonism reduces pro-contractile depolarizing membrane currents and inhibits elevations in intracellular calcium to promote relaxation of both murine and human uterine smooth muscle $(25,26)$. However, classic ANO1 antagonists possess low potency and selectivity for ANO1. Although ANO1 inhibitors such as CaCCinh-A01, T16Ainh-A01, MONNA (MN), tannic acid (TA), and benzbromarone (BB) (Fig. 1) have been identified (20, 27-29), studies simultaneously comparing their potency in the myometrium are lacking. While little is known concerning the safety profile of most of these drugs in vivo (especially in pregnancy), three of the compounds do belong to drug classes with known medicinal effects (gallotannins, anthranilic acid derivatives, and benzofurans). In this study, we questioned if functional differences exist between representatives of these three drug classes with known ANO1 antagonist properties and if a particular compound possesses statistically superior functional inhibition of human uterine smooth muscle contractility. 
A

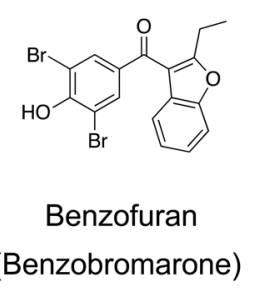

B

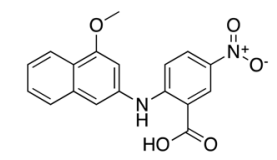

Anthranilic acid derivatives (MONNA)
C

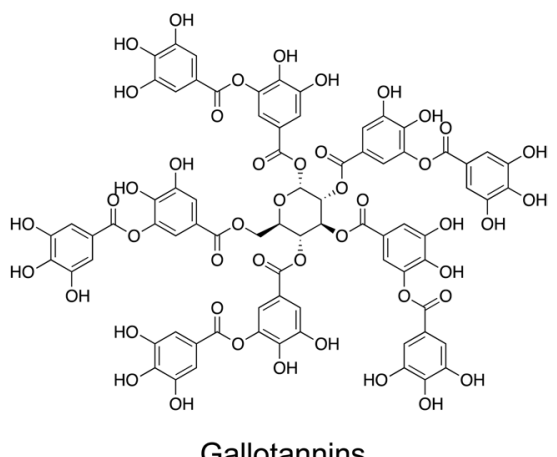

(Tannic acid)

Fig. 1. Chemical structure of second generation calcium activated chloride channel (anoctamin; ANO) antagonists. A: Benzofurane (Benzbromarone): (3,5-dibromo-4-hydroxyphenyl)-(2-ethyl-1-benzofuran-3-yl)methanone, B: Anthranilic acid derivatives (MONNA): N-((4-methoxy)-2-naphthyl)5-nitroanthranilic acid, C: Gallotannins (Tannis acid): 2,3-dihydroxy-5-(\{[(2R,3R,4S,5R,6R)$3,4,5,6$,-tetrakis( $\{3,4$-dihydroxy-5-\{(3,4,5-trihydroxyphenyl)carbonyloxy $\}$ phenyl $\}$ carbonyloxy) oxan-2-yl]methoxy $\}$ carbonyl)phenyl3,4,5,trihydroxybenzoate.

\section{Methods}

\section{Reagents/Chemicals}

All reagents were purchased from Sigma-Aldrich unless stated otherwise. BB and MN were dissolved in dimethyl sulfoxide (DMSO). TA were dissolved in double distilled water $\left(\mathrm{ddH}_{2} \mathrm{O}\right)$.

\section{Human USM specimens}

In accordance with the Institutional Review Board (IRB)-approved protocol (\#AAAL4005), de-identified fresh human uterine tissue was obtained from the superior margin of the uterine incision performed following elective cesarean deliveries (> 38-40 weeks gestation). All tissue samples were from non-laboring patients. In all cases, the tissue was immediately placed in cold, sterile Hank's balanced salt solution (HBSS) on ice. The tissue samples were subsequently dissected to isolate smooth muscle strips for organ bath studies.

\section{Cell culture}

Human telomerase reverse transcriptase (HTERT) immortalized human USM cells were a gift from Dr. Darlene Dixon (National Institutes of Health, NIH) (30). The USM cells were seeded into a $75-\mathrm{cm}^{2}$ culture flask and grown in smooth muscle basal medium-2 (SmBm-2) with manufacturer's recommended additives (Lonza, Walkersville, MD, USA).

\section{Functional organ bath force and frequency recordings; dose-response studies to establish functional differences between three classes of known ANO1 antagonists}

Freshly obtained late gestation myometrium samples were finely dissected into $4 \times 6 \mathrm{~mm}^{2}$ strips and attached inferiorly to a fixed tissue hook in a 16-mL organ bath (Radnoti Glass Technology, Monrovia, CA) and superiorly to a Grass FT03 force transducer (Grass Telefactor, West Warwick, RI) using a silk thread. BioPac hardware and Acknowledge 3.7.3 software (Biopac Systems, Goleta, CA) were used to continuously record the muscle force. The uterine strips were equilibrated under $2.5 \mathrm{~g}$ of tension for $1 \mathrm{~h}$ in a modified Krebs-Henseleit 
buffer (concentration in mM: sodium chloride [ $\mathrm{NaCl}], 112.0$; potassium chloride [KCl], 5.0; calcium chloride $\left[\mathrm{CaCl}_{2}\right], 2.5$; magnesium sulfate $\left[\mathrm{MgSO}_{4}\right], 1.2$; sodium bicarbonate $\left[\mathrm{NaHCO}_{3}\right], 25.0$; monosodium phosphate $\left[\mathrm{NaH}_{2} \mathrm{PO}_{4}\right], 1.0$; and D-glucose, $\left.11.5, \mathrm{pH} 7.4\right)$. The buffer was warmed to $37^{\circ} \mathrm{C}$, replaced every $15 \mathrm{~min}$, and continuously bubbled with $95 \% \mathrm{O}_{2} / 5 \% \mathrm{CO}_{2}$. The muscle-force of intact uterine strips was measured in response to exogenous oxytocin $(0.5 \mu \mathrm{M})$ over $60 \mathrm{~min}$. Following contractile stimulation with oxytocin $(0.5 \mu \mathrm{M})$, the strips were allowed to equilibrate at increased baseline contractility for $60 \mathrm{~min}$, and then they were treated with varying concentrations of ANO1 antagonists (BB, MN, and TA, $1-500 \mu \mathrm{M})$ or the vehicle $(0.1 \% \mathrm{DMSO})$ as a control. Following the addition of these drugs, the muscle force was analyzed over the next 60 min to examine the changes in the percentage integral force $(\mathrm{g} \cdot \mathrm{s})$ and frequency (contractions from baseline/hour), compared to both time-matched and vehicle-treated controls.

\section{Calcium flux studies; dose-response studies to establish functional differences between three classes of known ANO1 antagonists}

All intracellular calcium measurements were performed using the ratiometric fluorescent calcium indicator Fura-2 (Calbiochem, Billerica, MA, USA) as previously described (31). Human USM cells were grown to $100 \%$ confluence in 96 -well black-walled clear-bottom plates and were used between passages 4 and 8 . Cells were washed with modified HBSS (concentration in $\mathrm{mM}: \mathrm{NaCl}, 137.9 ; \mathrm{KCl}, 5.3 ; \mathrm{CaCl}_{2}, 2.0 ; \mathrm{MgSO}_{4}$, 1.0; Hepes, 2.4; and glucose, 5.5; $\mathrm{pH}$ to 7.4). The cells were then loaded with $100 \mu \mathrm{L}$ of $5 \mu \mathrm{M}$ Fura-2 AM in a humidified $37{ }^{\circ} \mathrm{C}$ incubator $\left(95 \%\right.$ air $\left./ 5 \% \mathrm{CO}_{2}\right)$ for $30 \mathrm{~min}$. Cells were washed again with HBSS and then incubated in HBSS for $20 \mathrm{~min}$ to allow de-esterification of the indicator. The cells were pretreated (10 min) with either an ANO1 specific antagonist (BB, MN, and TA) or vehicle, followed by oxytocin $1 \mu \mathrm{M}$ to induce $\mathrm{G}$ protein-coupled receptor (GPCR)-mediated calcium release.

\section{Membrane potential fluorescent assay; dose-response studies to establish functional differences between three classes of known ANO1 antagonists}

To determine whether inhibition of ANO 1 receptors induce membrane potential changes in cultured human uterine smooth muscle cells, the fluorometric imaging plate reader (FLIPR) in vitro fluorescent dye assay (Molecular Devices) was used as described by Wafford et al. (32). Briefly, human uterine smooth muscle cells were grown to $100 \%$ confluence in 96 -well black-walled plates and were washed with fresh warmed $\left(37^{\circ} \mathrm{C}\right)$ Krebs buffer [consisting of (in mM) $140 \mathrm{NaCl}, 4.7 \mathrm{KCl}, 2.5 \mathrm{CaCl}_{2}, 1.2 \mathrm{MgCl}_{2}, 10 \mathrm{D}$-glucose, and 11 HEPES, $\mathrm{pH}$ 7.4] three times. A stock solution (100\% dye) of FLIPR blue dye was prepared by reconstitution of 1 vial (125 mg) with $100 \mathrm{ml}$ of the Krebs buffer (assay buffer). A 50\% working stock was prepared by further diluting the reconstituted blue dye 1:1 with assay buffer and was used to load cells $\left(90 \mu \mathrm{l} /\right.$ well) over $30 \mathrm{~min}$ at $37^{\circ} \mathrm{C}$. All reagents were dissolved in assay buffer. Uterine smooth muscle cells were exposed to varying concentrations of ANO1 antagonists (BB, MN or TA; $0-500 \mu \mathrm{M}$ final) to determine a dose response. DMSO $(0.1 \%)$ (vehicle control), NS1619 (100 $\mu \mathrm{M}$ final) a control for membrane hyperpolarization or K-gluconate $(40 \mathrm{mM}$ final) a control for depolarization were used in parallel wells. All drug additions were performed with the auto-injector feature of a Flex Station III plate reader (Molecular Devices). The fluorescence produced by membrane potential change following solution additions was quantified after subtracting changes induced by vehicle control. The efficacy of the compound was determined from the $\%$ changes in area under curve (AUC) from vehicle control. 


\section{Statistical analysis}

Unless otherwise stated, the data were analyzed using a one-way analysis of variance (ANOVA) with the Bonferroni correction for multiple comparisons or unpaired two-tailed $t$-tests (for comparing two groups) where appropriate. The data are expressed as the mean \pm standard error (SE) and a $P<0.05$ was considered statistically significant. Dose-response curves were constructed using a four parameter logistic equation from GraphPad Prism software as follows: [Y=Bottom + (Top-Bottom) $/\left(1+10^{\wedge}((\operatorname{LogEC} 50-\mathrm{X}) *\right.$ HillSlope $\left.\left.)\right)\right]$.

\section{Results}

\section{Functional differences exist between the three classes of known ANO1 antagonists}

We investigated the functional differences between the effects of the three classes of ANO1 antagonists on USM contractility using ex vivo human uterine tissue strips (Fig. 2). Dose-response studies of BB, MN, and TA $(1-500 \mu \mathrm{M})$ demonstrated a dose-dependent reduction in force and frequency of contractions in human late gestation myometrial strips pre-contracted with oxytocin (Fig. 2A). The half-maximal inhibitory concentration $\left(\mathrm{IC}_{50}\right)$ values of $\mathrm{BB}, \mathrm{MN}$, and TA on oxytocin-induced contractility of human USM were 34,59 , and 45 $\mu \mathrm{M}$, respectively. Additionally, we observed significant differences in the minimum effective concentration to achieve statistical significance with BB being the most sensitive $(10 \mu \mathrm{M}, * P<0.05)$, followed by TA $(25 \mu \mathrm{M}$, $* * P<0.01)$ and $\mathrm{MN}(50 \mu \mathrm{M}, * * * P<0.001)$. Furthermore, comparison of the maximal inhibition demonstrated it was equivalent between $\mathrm{BB}$ and $\mathrm{MN}$ and was achieved at $100 \mu \mathrm{M}(* * * P<0.001)$. However, TA did not achieve complete functional inhibition of contractile force (Fig. 2B). With regard to frequency, the data are expressed as percent changes from baseline frequency/hour and is analyzed using a one-way ANOVA and Bonferroni's multiple comparison test to detect statistical significance compared to the vehicle control. ANO1 antagonism mediated by $\mathrm{BB}(1 \mu \mathrm{M}, * * * P<0.001)$, $\mathrm{MN}$, or TA (both $10 \mu \mathrm{M}, * * * P<0.001)$ significantly reduced the frequency (Fig. 2C).

\section{Reduction of peak intracellular calcium elevation associated with ANO1 antagonist-mediated inhibition of oxytocin-induced calcium release}

To investigate the cellular mechanisms involved in relaxation induced by BB, MN and TA, the effects on Gq-coupled oxytocin-induced increases in intracellular calcium were investigated. Figure 3A is a representative tracing of Fura-2 fluorescence versus time, with $1 \mu \mathrm{M}$ oxytocin added. In cells pretreated for 10 min with a varying concentrations of ANO 1 antagonist (BB, MN and TA, $1 \mu \mathrm{M}-500 \mu \mathrm{M}$ ), oxytocin mediated increases in intracellular calcium are suppressed. All tested ANO1 antagonists reduced oxytocin-mediated elevation in intracellular calcium in a dose-dependent manner (Fig. 3B). The $\mathrm{IC}_{50}$ values of BB, MN, and TA on oxytocininduced intracellular calcium elevation of human USM cells were 39, 48, and $53 \mu \mathrm{M}$, respectively. Specifically, we demonstrated that BB was the most sensitive drug based on its significant reduction in calcium flux at 10 $\mu \mathrm{M}$ compared to both $\mathrm{MN}$ and $\mathrm{TA}$, which showed significant effects at $25 \mu \mathrm{M}$. Moreover, the maximal inhibition by all the drugs was equivalent $(100 \mu \mathrm{M}, * * * P<0.001)$.

\section{Three different classes of ANO1 antagonists hyperpolarize human uterine smooth muscle cells detected by a fluorescent potentiometric indicator}

$\mathrm{BB}, \mathrm{MN}$ and TA's ability to change membrane potential as a contributing mechanism to relaxation was also investigated utilizing human uterine smooth muscle cells in cluture. FLIPR membrane potentiometric dye was used to assess whether these three classes of ANO1 antagonists hyperpolarized uterine smooth muscle 

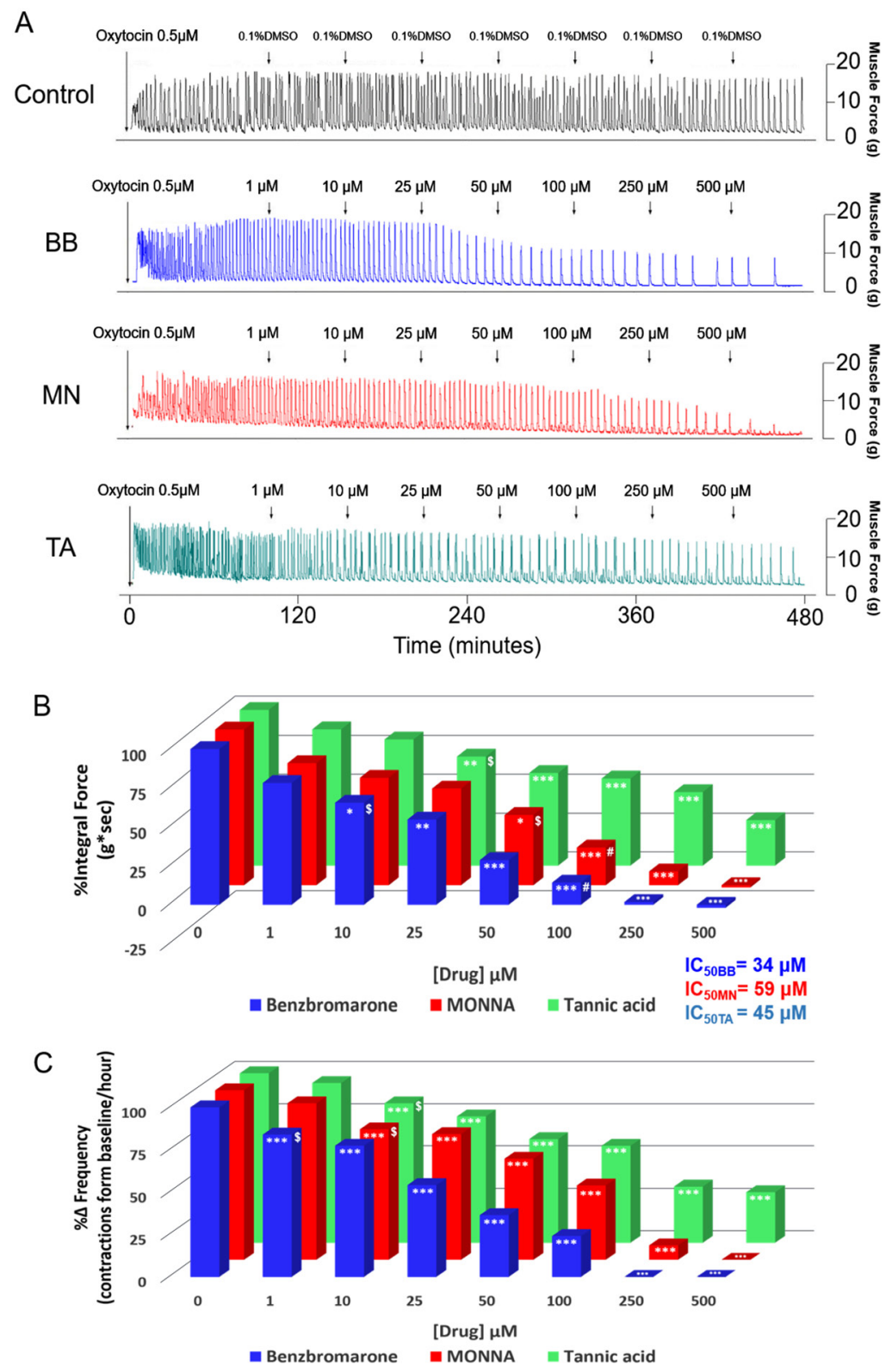

Fig. 2. Comparative pharmacological antagonism of human uterine smooth muscle (USM) anoctamin-1 on oxytocininduced enhanced force. A: Representative force tracing showing the differential potency $(\mathrm{BB}>\mathrm{MN}>\mathrm{TA})$ of $\mathrm{BB}$ (blue tracing), $\mathrm{MN}$ (red tracing) and TA (green tracing) on contractive frequency and force compared to vehicle control (black tracing). B: Determination of the half-maximal inhibitory concentration $\left(\mathrm{IC}_{50}\right)$, minimum effective dose and maximal inhibition $\left(\mathrm{I}_{\max }\right)$. Percent reduction in integral force $(\mathrm{g} * \mathrm{sec})$ calculated from baseline oxytocin contractility was plotted using a variable slope sigmoidal dose-response curve [Y=Bottom + (Top-Bottom)/ $\left(1+10^{\wedge}\left(\left(\log \mathrm{EC}_{50}-\mathrm{X}\right)^{*}\right.\right.$ HillSlope $\left.\left.)\right)\right]$. The $\mathrm{IC}_{50}$ of $\mathrm{BB}, \mathrm{MN}$ and $\mathrm{TA}$ on Oxytocin-induced contractility of human USM is $34 \mu \mathrm{M}, 59 \mu \mathrm{M}$ or $45 \mu \mathrm{M}$ respectively. One way ANOVA with Bonferroni's Multiple Comparison Test was used to statistically analyze differences between groups. We see statistical differences in minimum effective concentrations (\$) with BB being most sensitive $(10 \mu \mathrm{M} ; * P<0.05)$, followed by TA $(25 \mu \mathrm{M} ; * * P<0.01)$, followed by $\mathrm{MN}(50 \mu \mathrm{M} ; * * *<0.001)$. With respect to comparative maximal inhibition (Imax; $\#)$, we demonstrate equivalent Imax between $\mathrm{BB}$ and $\mathrm{MN}$ achieved at $100 \mu \mathrm{M}(* * * P<0.001)$, with TA never achieving complete functional force inhibition ( $n=32$ samples from 5 different patients). C: Determination of contraction frequency. The data is expressed as percent changes from baseline frequency/hour and analyzed using one way ANOVA and Bonferroni's Multiple Comparison Test to detect statistical significance from the vehicle control. ANO1 antagonism mediated by BB at $1 \mu \mathrm{M}(* * * P<0.001), \mathrm{MN}$ at $10 \mu \mathrm{M}(* * * P<0.001)$ or TA at $10 \mu \mathrm{M}(* * * P<0.001)$ allowed for statistically significant reductions in frequency. ${ }^{*} \mathrm{BB}=$ benzbromarone, $\mathrm{MN}=\mathrm{MONNA}, \mathrm{TA}=$ tannic acid $(n=32$ samples from 5 different patients). 

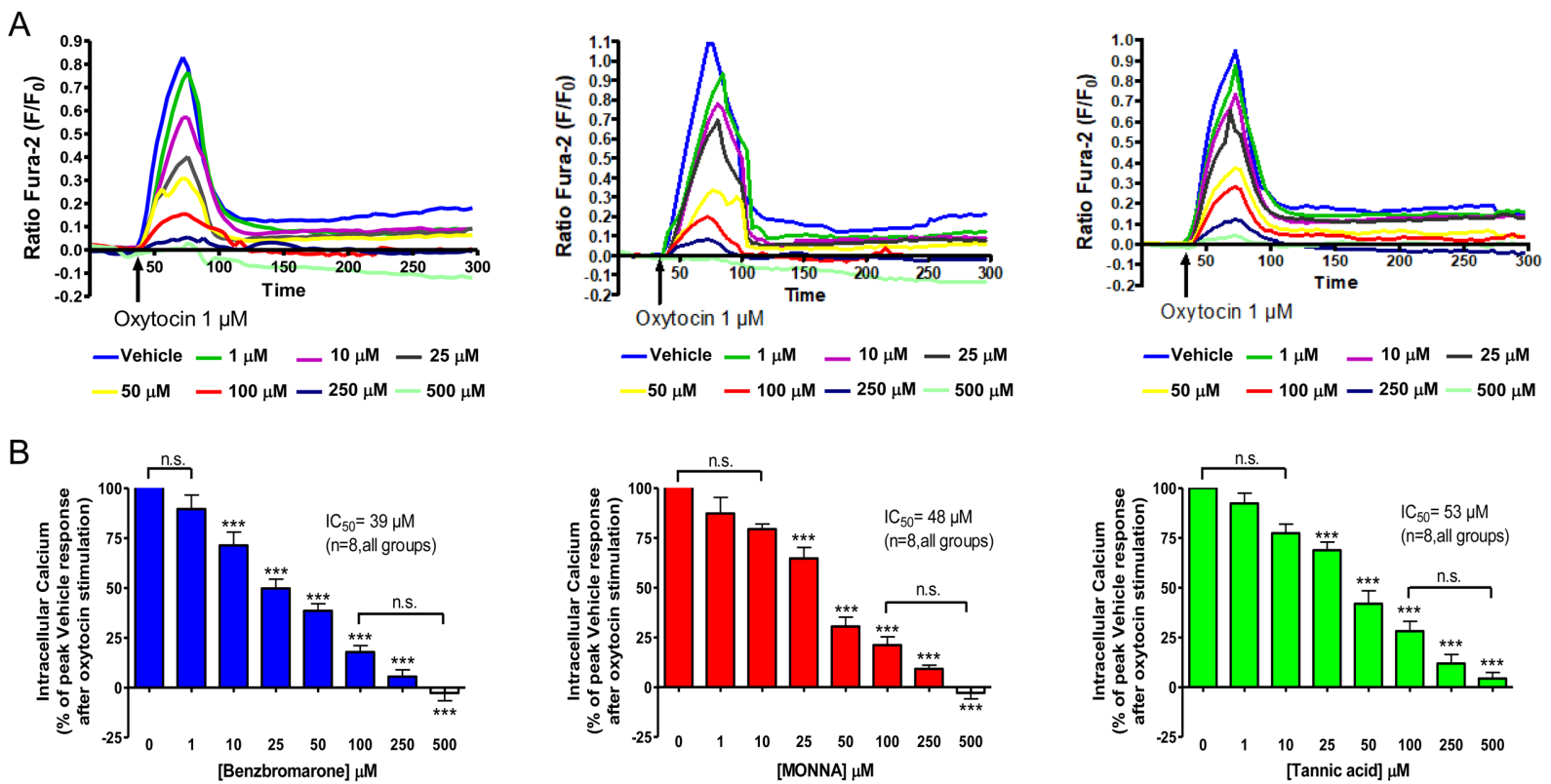

Fig. 3. Peak intracellular calcium response to Gq coupled agonist after pretreatment with ANO1 antagonists. A: Representative tracing of Fura-2 fluorescence versus time, with $1 \mu \mathrm{M}$ oxytocin added. In cells pretreated for 10 min with a varying doses of ANO1 antagonist (BB, MN and TA, $1 \mu \mathrm{M}-500 \mu \mathrm{M})$, oxytocin mediated increase in intracellular calcium is suppressed. B: Determination of the half-maximal inhibitory concentration $\left(\mathrm{IC}_{50}\right)$, subthreshold dose and maximal inhibition $\left(\mathrm{I}_{\max }\right)$. One way ANOVA with Bonferroni's Multiple Comparison Test was used to statistically analyze differences between groups. The $\mathrm{IC}_{50}$ values of $\mathrm{BB}, \mathrm{MN}$, and TA on oxytocin-induced intracellular calcium elevation of human USM cells were 39,48 , and $53 \mu \mathrm{M}$, respectively. The sub-threshold concentration for $\mathrm{BB}, \mathrm{MN}$ and $\mathrm{TA}$ on oxytocin-induced contractility is $1 \mu \mathrm{M}, 10 \mu \mathrm{M}$ or $10 \mu \mathrm{M}$ respectively $(* * * P<0.001) . \mathrm{I}_{\max }$ is equivalent between all three drugs. $* \mathrm{BB}=$ benzbromarone, $\mathrm{MN}=\mathrm{MONNA}, \mathrm{TA}=$ tannic acid ( $n=8$, all groups from 8 different experiments).

cells. Potassium gluconate $40 \mathrm{mM}$ was used as a positive control as a depolarizing agent, and $100 \mu \mathrm{M}$ NS1619 (BKCa channel opener) was used as a positive control as a hyperpolarizing agent. Representative illustration of fluorescent changes under conditions of ANO 1 receptor antagonism are shown in Fig. 4A. The $\mathrm{IC}_{50}$ of BB, $\mathrm{MN}$ and TA on membrane depolarization of cultured human uterine smooth muscle cells is $55 \mu \mathrm{M}, 163 \mu \mathrm{M}$ and $97 \mu \mathrm{M}$, respectively. One way ANOVA with Bonferroni's multiple comparison test was used to statistically analyze differences between groups. There were significant differences in the minimum effective concentrations with BB being most sensitive $(50 \mu \mathrm{M} ; * * * P<0.001)$, followed by TA $\left(100 \mu \mathrm{M} ;{ }^{*} P<0.5\right)$, followed by MN $(250 \mu \mathrm{M} ; * * P<0.01)$ (Fig. 4B).

\section{Discussion}

This study highlights the functional differences among three distinct classes of ANO1 antagonists in human USM tissue and cells. The ultimate goal of this study was to compare representatives from three drug classes (gallotannins, anthranilic acid derivatives, and benzofurans) with known ANO1/TMEM16A antagonism in their capacity to serve as tocolytics. However, as shown by Fig. 1 - there is significant chemical structural differences between these compounds despite reported selectivity for TMEM16A/ANO1 inhibition. Therefore, our study is unique in that we screened representatives from each of these drug classes in parallel using human USM tissue and cells in functionally relevant experimental platforms. This is important because most screening studies of ANO1 antagonists have use high-throughput assays in heterologous over-expression 
A (i)

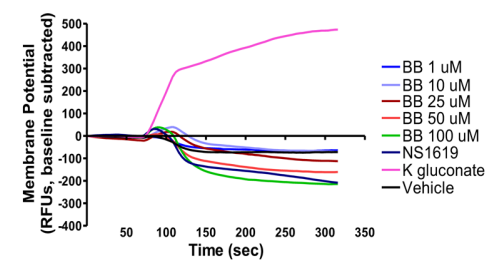

B (i)

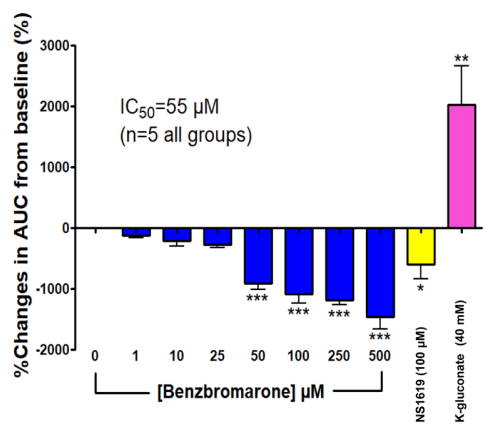

(ii)

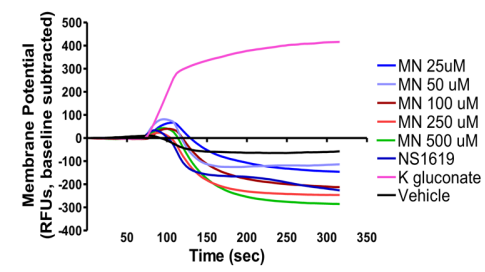

(ii)

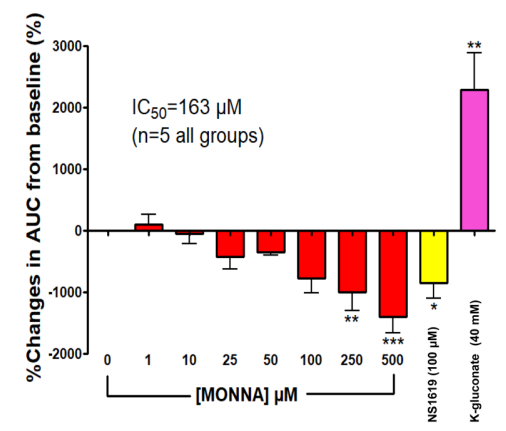

(iii)

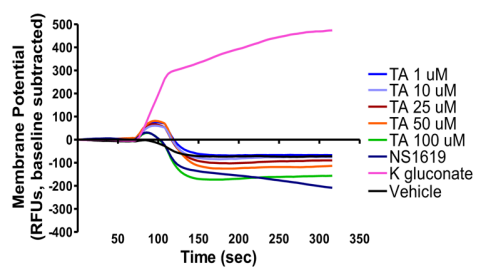

(iii)

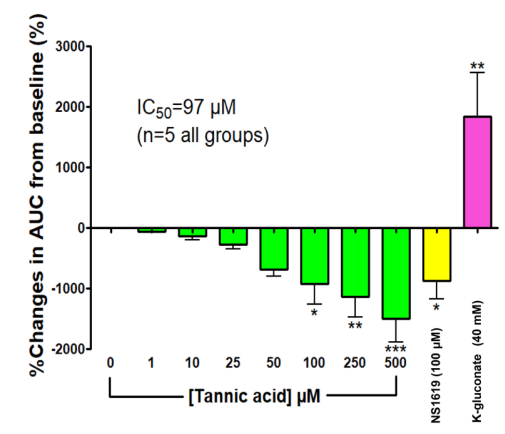

Fig. 4. Membrane potential changes in cultured human uterine smooth muscle cells detected by a fluorescent potentiometric indicator. A: Representative illustration of fluorescent changes under conditions of ANO 1 receptor antagonism. (i) Benzbromarone (BB, 0-100 $\mu \mathrm{M}$ ), (ii) MONNA (MN, 25-500 $\mu \mathrm{M}$ ), (iii) Tannic acid (TA, 0-100 $\mu \mathrm{M}$ ). $\mathrm{B}$ : Determination of the half-maximal inhibitory concentration $\left(\mathrm{IC}_{50}\right)$ and minimum effective concentrations for membrane depolarization. Percent reduction in area under curve (AUC) calculated from baseline (vehicle control) was plotted using a variable slope sigmoidal dose-response curve $\left[\mathrm{Y}=\mathrm{Bottom}+(\right.$ Top-Bottom $) /\left(1+10^{\wedge}\left(\left(\operatorname{LogEC} \mathrm{C}_{50^{-}}\right.\right.\right.$ $\mathrm{X})^{*}$ HillSlope))]. The $\mathrm{IC}_{50}$ of $\mathrm{BB}, \mathrm{MN}$ and $\mathrm{TA}$ on membrane depolarization of cultured human uterine smooth muscle cells is $55 \mu \mathrm{M}, 163 \mu \mathrm{M}$ or $97 \mu \mathrm{M}$ respectively. One way ANOVA with Bonferroni's Multiple Comparison Test was used to statistically analyze differences between groups. We see statistical differences in minimum effective concentrations with BB being most sensitive $(50 \mu \mathrm{M} ; * * *<0.001)$, followed by TA $(100 \mu \mathrm{M} ; * P<0.5)$, followed by $\mathrm{MN}(250 \mu \mathrm{M} ; * * P<0.01)$. NS1619 $(100 \mu \mathrm{M})$ is a negative control and K-gluconate $(40 \mathrm{mM})$ is a positive control $(* P<0.5, * * P<0.01)$. ( $n=5$, all groups from 7 different experiments).

cell platforms or in animal models that do not model human pregnant USM physiology well (20).

We believe this is of particular importance with regard to ANO1 since there is evidence that not all tissue types express the same complement of ANO1 splice variants $(33,34)$, there is incomplete homology of ANO1 variant expression between humans and mice (35), and differences in ANO1 splice variation can significantly change channel properties $(36,37)$. Given these concerns, we chose to exclusively use human pregnant USM in our organ bath experiments to screen ANO1 antagonism effects in order to more closely mimic the clinical milieu under which tocolysis is needed. Our primary focus was to look at relaxation parameters using ex vivo organ bath to examine direct muscle force and frequency differences. In organ bath studies, we demonstrate that $\mathrm{BB}$ (benzofuran drug class) is the most potent antagonist studied with respect to force inhibition (at 10 $\mu \mathrm{M} ; * P<0.05)$ compared to $\mathrm{MN}$ and $\mathrm{TA}$, which showed significant effects in force at $50 \mu \mathrm{M}\left({ }^{*} P<0.05\right)$ or $25 \mu \mathrm{M}(* * P<0.01)$, respectively (Fig. $2 \mathrm{~B})$. With respect to frequency inhibition (Fig. $2 \mathrm{C}$ ), we demonstrated that $\mathrm{BB}$ achieved its significant reduction at $1 \mu \mathrm{M}(* * * P<0.001)$ compared to both $\mathrm{MN}$ and TA, which showed significant effects at $10 \mu \mathrm{M}(* * * P<0.001)$. To insure appropriate comparisons were made, all three drugs were assessed in parallel on samples from the same patient.

Our secondary focus was to relate our functional force findings to mechanistically related experimental assays in human smooth muscle cells. Forceful uterine contractions are thought to depend on local AP generation and propagation of this AP facilitated through the tissue. Two critical events tied to AP generation include 
a shift in USM cell membrane potential to a more depolarized state and elevations in evoked intra-cellular calcium levels (38). Although the role of calcium in promoting myometrial contractility has been well established, the ionic contributions leading up to AP generation and ionic modulation of intracellular calcium dynamics remain incompletely understood. Nevertheless, ion channel modulation can limit AP firing and reduce myometrial calcium flux to facilitate USM tocolysis $(39,40)$. Indeed, initial evidence for CaCCs role in myometrial contractility was first provided in studies examining rat myometrium which described a prominent inward (depolarizing) current that reduced the AP firing frequency of myometrial cells (7). Although these investigators did not identify the actual ion channels responsible for their observations, they did demonstrate ubiquitous chloride channel blockade resulted in a significant reduction in the frequency of $\mathrm{Ca}^{2+}$ transients. In this paper, we demonstrate all 3 ANO1 antagonists block oxytocin-induced calcium elevation (Fig. 3). Comparatively, we demonstrate that $\mathrm{BB}$ exhibits significantly higher potency in reduction of calcium flux at $10 \mu \mathrm{M}(* * * P<0.001)$ compared to both MN and TA, which showed significant effects at $25 \mu \mathrm{M}(* * * P<0.001)$.

Consistent with these observations, our laboratory has previously shown in human and murine USM cells that ANO1/2 channel activity provides depolarizing currents, and that antagonism of these channels limits pro-contractile calcium release in both murine and human USM $(25,26)$. This is in agreement with observations studying the role of ANO1 in other tissues. In several studies, ANO1 has been shown to be an important contributor to shifting resting membrane potentials from a relatively negative potential to more positive thresholds $(41,42)$. In USM, the shift in resting membrane potential to more positive (depolarized) potential is a critical event required for activation of VGCC to reach AP threshold (43). Given the mechanistic importance of membrane potential, we tested the 3 ANO1 antagonists ability to suppress these critical contributors to AP generation by examining the ability of each ANO1 antagonists to elicit membrane hyperpolarization in a dose-dependent manner (Fig. 4). In FLIPR studies, there were significant differences in the minimum effective concentrations with BB being most sensitive $(50 \mu \mathrm{M}$; ***P<0.001), followed by TA $(100 \mu \mathrm{M}$; *P<0.05), followed by $\mathrm{MN}(250 \mu \mathrm{M} ; * * P<0.01)$. We found concordance between our cellular and tissue experiments, with BB being the most potent compound studied.

In general, studies on CaCCs have been historically limited because of a paucity of specific pharmacologic antagonists. However, following the identification of ANO1 as a CaCC channel in 2008 (17-19) more selective antagonists have been developed. For example, Huang et al. identified BB as a potent ANO1-specific antagonist via high-throughput screening (21). Other CaCC inhibitors, such as TA (44), T16Ainh-A01 (20), MN (28), B25 (45) and Ani9 (46) have also been identified and characterized as ANO1 inhibitors. We specifically chose representatives from three drug classes known to possess medicinal effects in humans. The three drugs and their respective families included TA (gallotannin family), MN (anthranilic acid derivative family) and BB (benzofuran family). Although TA was reported to be an effective inhibitor of ANO1 on screening of a chemical library with a high representation of gallotannin compounds, it also inhibits ANO2 as well as ANO1 (44). In our study, treatment with TA yielded moderately potent force and frequency inhibition but exhibited relatively poor maximal inhibition of force. This interesting ex vivo finding may be related to TA's chemical structure. All gallotannins represent polymers of galloyl units bound to diverse polyol units (D-glucose derivatives) (47). Given that certain members of this family can possess a large number of galloyl moieties (ranging from 2 to 12 per molecule) they can be rather bulky. While TA commonly may represent a mixture these compounds with variable amounts of galloyl moieties, pharmaceutical grade TA is commonly isolated as a decagalloyl glucose ( 10 moeties, Fig. 1C). Since we used pharmaceutical grade TA, we suspect that steric hindrance and issues related to reduced tissue penetration may be responsible for the lack of maximal force inhibition we observed in our organ bath studies. For example, the molecular weight of TA is 1,701.20 whereas 
that of BB or MN is 424.08 or 338.31, respectively. Furthermore, TA has higher water solubility, which can restrict tissue penetration. This may account for the differences in effectiveness we observed between cultured cell effects and whole tissue effects for TA. Interestingly we observed no issues with maximal inhibition using TA in our cell culture studies, suggesting drug penetrance may have been compromised for tissue, but not for a monolayer of cells. TA is abundant in certain foods (nettles, berries and nuts) and beverages like tea and wine. As a mixed herbal form, TA reportedly has anti-microbial, anti-oxidant and anti-mutagenic properties $(48,49)$. While it is generally considered safe to take orally in quantities commonly found in food (50), there are serious concerns about high levels of systemic tannic acids and negative health effects including anemia, renal and hepatic toxicity (51-53). Given these concerns, as a systemic supplement the use of TA as a tocolytic is not recommended in pregnancy. However, while TA was the least potent among the 3 compounds we tested, its structure may lend some insights into improved ANO1 antagonist development.

In a recent study, the evaluation of a select panel of anthranilic acid derivatives facilitated the identification of a potent ANO1 inhibitor, termed MN (28). Selectivity tests of MN revealed that other chloride channels such as bestrophin-1, chloride channel protein 2, and cystic fibrosis transmembrane conductance regulator were not blocked by $\mathrm{MN}(10-30 \mu \mathrm{M})$ suggesting $\mathrm{MN}$ is the most selective ANO1 antagonist studied to date (28). However, in another study MONNA displayed enhanced ANO1 selectivity (over ANO2). In this study, MONNA inhibits whole-cell current recordings from HEK293T cells expressing mouse ANO1, while ANO2 currents remained largely intact even at high doses of MONNA (54). In our studies, when compared to BB, $\mathrm{MN}$ induced less potent force inhibition. However, it showed an equivalent maximal inhibition with respect to force, frequency, and calcium inhibition. Although MN has not been administered to patients, it is an anthranilic acid derivative and is structurally similar to mefanamic acid (55). Mefenamic acid is an inhibitor of COX, and has been used predominantly in Europe where it was prescribed to treat pain and migraines associated with menstruation (56-58). Interestingly, this compound has been used in pregnancy and 1 study reported a positive benefit as a treatment for preterm labor (59). This study had a very high rate of preterm delivery in the control group (40\%), and mefenamic acid was not further pursued as a tocolytic with subsequent studies. While this study has not been reproduced, it is intriguing to speculate if some of its potential tocolytic activity relates to ANO1 inhibition. However, although MN has not been specifically shown to possess COX inhibition, use of other anthranilic acid derivatives (including mefanamic acid) in pregnancy is cautioned against due to increased risk of premature closure of the fetal ductus arteriosus and oligohydramnios (60).

BB was first identified as an ANO1 inhibitor following the screening of a relatively small chemical library (21). Chemically, the Benzofuran family members are characterized as a heterocyclic compound comprising a fused benzene and furan ring (Fig. 1A). This arrangement offers some advantages for novel compound synthesis. In fact, several benzofuran derivatives have been produced with novel anti-oxidant and anti-microbial activity, suggesting that BB may be amenable to modification that might enhance its selectivity for ANO1 $(61,62)$. While BB did prove in our studies to be the most potent ANO1 antagonist studied, it does have nonspecific effects on other proteins. In particular, BB has been used clinically in humans as a treatment for gout (63) given its ability to also act as a xanthine oxidase inhibitor (64). Interestingly, another xanthine oxidase inhibitor (allopurinol) have been administered to pregnant women without any untoward effects on labor, suggesting the relaxant effects we observe in USM are not related to XO inhibition. In addition, there are reports of hepatotoxicity related to BB treatment that did lead to its withdrawal from the markets of some countries in $2003(65,66)$. While its safety has never been assessed in pregnancy, these side effects should be taken into account if $\mathrm{BB}$ is developed as a new tocolytic drug. Therefore, given its ex vivo effectiveness as a tocolytic we can only speculate as to whether structural optimization of BB or co-treatment with other classic tocolytic 
drugs (e.g. calcium channel blockers and $\beta 2$ adrenergic receptor agonists) may allow for drug synergy and reduced side effect profiles. Promising studies are now underway looking at the potentiation these tocolytics when used in combination.

We utilized BB, MN, and TA in these studies because of their reported potency, specificity, and effectiveness targeting ANO1 in smooth muscle relaxation (67). However, previous studies were limited by the fact that the majority of the drug screens were not performed in endogenous tissues of clinical interest (22,33-35) but instead used engineered cell platforms for high-throughput, which may or may not resemble tissue-specific ANO1 expression patterns. In summary, we have demonstrated the pharmacological characteristics of three different classes of ANO1 antagonists, which may prove valuable for in silico modeling for further future ANO1 selective drug development. Furthermore, we suggest all tocolytic drug screens utilize similar ex vivo screening paradigm. Thus, our study provides evidence that the benzofuran class of ANO1 antagonists may be useful as tocolytics in the future.

\section{Conflict of interest}

The authors declare that they have no conflict of interest.

\section{References}

1. Blencowe H, Cousens S, Oestergaard MZ, Chou D, Moller AB, Narwal R, Adler A, Vera Garcia C, Rohde S, Say L, Lawn JE. National, regional, and worldwide estimates of preterm birth rates in the year 2010 with time trends since 1990 for selected countries: a systematic analysis and implications. Lancet. 2012; 379(9832): 2162-72. [Medline] [CrossRef]

2. Liu L, Oza S, Hogan D, Chu Y, Perin J, Zhu J, Lawn JE, Cousens S, Mathers C, Black RE. Global, regional, and national causes of under-5 mortality in 2000-15: an updated systematic analysis with implications for the Sustainable Development Goals. Lancet. 2016; 388(10063): 3027-35. [Medline] [CrossRef]

3. Simhan HN, Caritis SN. Prevention of preterm delivery. N Engl J Med. 2007; 357(5): 477-87. [Medline] [CrossRef]

4. Iams, JD. Clinical practice. Prevention of preterm parturition. The New England journal of medicine. Jan 16; 370(3): 254-61.

5. Younger JD, Reitman E, Gallos G. Tocolysis: Present and future treatment options. Semin Perinatol. 2017; 41(8): 493-504. [Medline] [CrossRef]

6. Haas DM, Caldwell DM, Kirkpatrick P, McIntosh JJ, Welton NJ. Tocolytic therapy for preterm delivery: systematic review and network meta-analysis. BMJ. 2012; 345: e6226. [Medline] [CrossRef]

7. Jones K, Shmygol A, Kupittayanant S, Wray S. Electrophysiological characterization and functional importance of calcium-activated chloride channel in rat uterine myocytes. Pflugers Arch. 2004; 448(1): 36-43. [Medline] [CrossRef]

8. Cotton KD, Hollywood MA, McHale NG, Thornbury KD. $\mathrm{Ca}^{2+}$ current and $\mathrm{Ca}\left({ }^{2+}\right)$-activated chloride current in isolated smooth muscle cells of the sheep urethra. J Physiol. 1997; 505(Pt 1): 121-31. [Medline] [CrossRef]

9. Saleh SN, Greenwood IA. Activation of chloride currents in murine portal vein smooth muscle cells by membrane depolarization involves intracellular calcium release. Am J Physiol Cell Physiol. 2005; 288(1): C122-31. [Medline] [CrossRef]

10. Hashitani H, Van Helden DF, Suzuki H. Properties of spontaneous depolarizations in circular smooth 
muscle cells of rabbit urethra. Br J Pharmacol. 1996; 118(7): 1627-32. [Medline] [CrossRef]

11. Marshall JM. Regulation of activity in uterine smooth muscle. Physiol Rev. Suppl. 1962; 5: $213-27$. [Medline]

12. Young RC, Bemis A. Calcium-activated chloride currents prolongs the duration of contractions in pregnant rat myometrial tissue. Reprod Sci. 2009; 16(8): 734-9. [Medline] [CrossRef]

13. Arnaudeau S, Leprêtre N, Mironneau J. Chloride and monovalent ion-selective cation currents activated by oxytocin in pregnant rat myometrial cells. Am J Obstet Gynecol. 1994; 171(2): 491-501. [Medline] [CrossRef]

14. Coleman HA, Parkington HC. Single channel $\mathrm{Cl}^{-}$and $\mathrm{K}^{+}$currents from cells of uterus not treated with enzymes. Pflugers Arch. 1987; 410(4-5): 560-2. [Medline] [CrossRef]

15. Kaya T, Guvenal T, Karadas B, Cetin A, Soydan AS. Effects of 5-nitro-2-(3-phenylpropylamino) benzoic acid, anthracene-9-carboxylate, and zaprinast on endothelin-1-induced contractions of pregnant rat myometrium. Eur J Obstet Gynecol Reprod Biol. 2002; 105(2): 114-9. [Medline] [CrossRef]

16. Yarar Y, Cetin A, Kaya T. Chloride channel blockers 5-nitro-2-(3-phenylpropylamino) benzoic acid and anthracene-9-carboxylic acid inhibit contractions of pregnant rat myometrium in vitro. J Soc Gynecol Investig. 2001; 8(4): 206-9. [Medline]

17. Yang YD, Cho H, Koo JY, Tak MH, Cho Y, Shim WS, Park SP, Lee J, Lee B, Kim BM, Raouf R, Shin YK, Oh U. TMEM16A confers receptor-activated calcium-dependent chloride conductance. Nature. 2008; 455(7217): 1210-5. [Medline] [CrossRef]

18. Caputo A, Caci E, Ferrera L, Pedemonte N, Barsanti C, Sondo E, Pfeffer U, Ravazzolo R, ZegarraMoran O, Galietta LJ. TMEM16A, a membrane protein associated with calcium-dependent chloride channel activity. Science. 2008; 322(5901): 590-4. [Medline] [CrossRef]

19. Schroeder BC, Cheng T, Jan YN, Jan LY. Expression cloning of TMEM16A as a calcium-activated chloride channel subunit. Cell. 2008; 134(6): 1019-29. [Medline] [CrossRef]

20. Namkung W, Phuan PW, Verkman AS. TMEM16A inhibitors reveal TMEM16A as a minor component of calcium-activated chloride channel conductance in airway and intestinal epithelial cells. J Biol Chem. 2011; 286(3): 2365-74. [Medline] [CrossRef]

21. Huang F, Zhang H, Wu M, Yang H, Kudo M, Peters CJ, Woodruff PG, Solberg OD, Donne ML, Huang X, Sheppard D, Fahy JV, Wolters PJ, Hogan BL, Finkbeiner WE, Li M, Jan YN, Jan LY, Rock JR. Calcium-activated chloride channel TMEM16A modulates mucin secretion and airway smooth muscle contraction. Proc Natl Acad Sci USA. 2012; 109(40): 16354-9. [Medline] [CrossRef]

22. Sanders KM, Zhu MH, Britton F, Koh SD, Ward SM. Anoctamins and gastrointestinal smooth muscle excitability. Exp Physiol. 2012; 97(2): 200-6. [Medline] [CrossRef]

23. Cho H, Yang YD, Lee J, Lee B, Kim T, Jang Y, Back SK, Na HS, Harfe BD, Wang F, Raouf R, Wood JN, Oh U. The calcium-activated chloride channel anoctamin 1 acts as a heat sensor in nociceptive neurons. Nat Neurosci. 2012; 15(7): 1015-21. [Medline] [CrossRef]

24. Gallos G, Remy KE, Danielsson J, Funayama H, Fu XW, Chang HY, Yim P, Xu D, Emala CW Sr. Functional expression of the TMEM16 family of calcium-activated chloride channels in airway smooth muscle. Am J Physiol Lung Cell Mol Physiol. 2013; 305(9): L625-34. [Medline] [CrossRef]

25. Bernstein K, Vink JY, Fu XW, Wakita H, Danielsson J, Wapner R, Gallos G. Calcium-activated chloride channels anoctamin 1 and 2 promote murine uterine smooth muscle contractility. Am J Obstet Gynecol. 2014; 211(6): 688.e1-10. [Medline] [CrossRef]

26. Danielsson J, Vink J, Hyuga S, Fu XW, Funayama H, Wapner R, Blanks AM, Gallos G. Anoctamin Channels in Human Myometrium: A Novel Target for Tocolysis. Reprod Sci. 2018; Jan 1: 1933719118757683; [Epub ahead of print]. [Medline]

27. Seo Y, Park J, Kim M, Lee HK, Kim JH, Jeong JH, Namkung W. Inhibition of ANO1/TMEM16A Chloride Channel by Idebenone and Its Cytotoxicity to Cancer Cell Lines. PLoS One. 2015; 10(7): e0133656. 
[Medline] [CrossRef]

28. Oh SJ, Hwang SJ, Jung J, Yu K, Kim J, Choi JY, Hartzell HC, Roh EJ, Lee CJ. MONNA, a potent and selective blocker for transmembrane protein with unknown function 16/anoctamin-1. Mol Pharmacol. 2013; 84(5): 726-35. [Medline] [CrossRef]

29. Bill A, Hall ML, Borawski J, Hodgson C, Jenkins J, Piechon P, Popa O, Rothwell C, Tranter P, Tria S, Wagner T, Whitehead L, Gaither LA. Small molecule-facilitated degradation of ANO1 protein: a new targeting approach for anticancer therapeutics. J Biol Chem. 2014; 289(16): 11029-41. [Medline] [CrossRef]

30. Carney SA, Tahara H, Swartz CD, Risinger JI, He H, Moore AB, Haseman JK, Barrett JC, Dixon D. Immortalization of human uterine leiomyoma and myometrial cell lines after induction of telomerase activity: molecular and phenotypic characteristics. Lab Invest. 2002; 82(6): 719-28. [Medline] [CrossRef]

31. Marshall IC, Boyfield I, McNulty S. Ratiometric $\mathrm{Ca}^{2+}$ measurements using the FlexStation(®)Scanning Fluorometer. Methods Mol Biol. 2013; 937: 95-101. [Medline] [CrossRef]

32. Wafford KA, van Niel MB, Ma QP, Horridge E, Herd MB, Peden DR, Belelli D, Lambert JJ. Novel compounds selectively enhance delta subunit containing GABA A receptors and increase tonic currents in thalamus. Neuropharmacology. 2009; 56(1): 182-9. [Medline] [CrossRef]

33. Ferrera L, Caputo A, Ubby I, Bussani E, Zegarra-Moran O, Ravazzolo R, Pagani F, Galietta LJ. Regulation of TMEM16A chloride channel properties by alternative splicing. J Biol Chem. 2009; 284(48): 33360-8. [Medline] [CrossRef]

34. Hwang SJ, Basma N, Sanders KM, Ward SM. Effects of new-generation inhibitors of the calcium-activated chloride channel anoctamin 1 on slow waves in the gastrointestinal tract. Br J Pharmacol. 2016; 173(8): 1339-49. [Medline] [CrossRef]

35. O’Driscoll KE, Pipe RA, Britton FC. Increased complexity of Tmem16a/Anoctamin 1 transcript alternative splicing. BMC Mol Biol. 2011; 12: 35. [Medline] [CrossRef]

36. Strege PR, Bernard CE, Mazzone A, Linden DR, Beyder A, Gibbons SJ, Farrugia G. A novel exon in the human $\mathrm{Ca}^{2+}$-activated $\mathrm{Cl}^{-}$channel Anol imparts greater sensitivity to intracellular $\mathrm{Ca}^{2+}$. Am $\mathrm{J}$ Physiol Gastrointest Liver Physiol. 2015; 309(9): G743-9. [Medline] [CrossRef]

37. Sung TS, O’Driscoll K, Zheng H, Yapp NJ, Leblanc N, Koh SD, Sanders KM. Influence of intracellular $\mathrm{Ca}^{2+}$ and alternative splicing on the pharmacological profile of ANO1 channels. Am J Physiol Cell Physiol. 2016; 311(3): C437-51. [Medline] [CrossRef]

38. Young RC. Tissue-level signaling and control of uterine contractility: the action potential-calcium wave hypothesis. J Soc Gynecol Investig. 2000; 7(3): 146-52. [Medline]

39. Sanborn BM. Relationship of ion channel activity to control of myometrial calcium. J Soc Gynecol Investig. 2000; 7(1): 4-11. [Medline] [CrossRef]

40. Shmygol A, Blanks AM, Bru-Mercier G, Gullam JE, Thornton S. Control of uterine $\mathrm{Ca}^{2+}$ by membrane voltage: toward understanding the excitation-contraction coupling in human myometrium. Ann N Y Acad Sci. 2007; 1101: 97-109. [Medline] [CrossRef]

41. Takayama Y, Uta D, Furue H, Tominaga M. Pain-enhancing mechanism through interaction between TRPV1 and anoctamin 1 in sensory neurons. Proc Natl Acad Sci USA. 2015; 112(16): 5213-8. [Medline] [CrossRef]

42. Crutzen R, Virreira M, Markadieu N, Shlyonsky V, Sener A, Malaisse WJ, Beauwens R, Boom A, Golstein PE. Anoctamin 1 (Anol) is required for glucose-induced membrane potential oscillations and insulin secretion by murine $\beta$-cells. Pflugers Arch. 2016; 468(4): 573-91. [Medline] [CrossRef]

43. Blanks AM, Zhao ZH, Shmygol A, Bru-Mercier G, Astle S, Thornton S. Characterization of the molecular and electrophysiological properties of the T-type calcium channel in human myometrium. J Physiol. 2007; 581(Pt 3): 915-26. [Medline] [CrossRef] 
44. Namkung W, Thiagarajah JR, Phuan PW, Verkman AS. Inhibition of Ca2+-activated Cl- channels by gallotannins as a possible molecular basis for health benefits of red wine and green tea. FASEB J. 2010; 24(11): 4178-86. [Medline] [CrossRef]

45. Kumar S, Namkung W, Verkman AS, Sharma PK. Novel 5-substituted benzyloxy-2-arylbenzofuran3-carboxylic acids as calcium activated chloride channel inhibitors. Bioorg Med Chem. 2012; 20(14): 4237-44. [Medline] [CrossRef]

46. Seo Y, Lee HK, Park J, Jeon DK, Jo S, Jo M, Namkung W. Ani9, A Novel Potent Small-Molecule ANO1 Inhibitor with Negligible Effect on ANO2. PLoS One. 2016; 11(5): e0155771. [Medline] [CrossRef]

47. McCreath SB, Delgoda R. Pharmacognosy fundamentals, applications and strategies. 1st ed. Amsterdam:Elsevier; 2017. Chapter 10, Tannins; p.199-232.

48. Serrano J, Puupponen-Pimiä R, Dauer A, Aura AM, Saura-Calixto F. Tannins: current knowledge of food sources, intake, bioavailability and biological effects. Mol Nutr Food Res. 2009; 53(Suppl 2): S31029. [Medline] [CrossRef]

49. Huang WY, Cai YZ, Zhang Y. Natural phenolic compounds from medicinal herbs and dietary plants: potential use for cancer prevention. Nutr Cancer. 2010; 62(1): 1-20. [Medline] [CrossRef]

50. U.S. Food and Drug Administration Title21 Food and drugs.Chapter 1 Food and drug administration. [Internet]. Maryland: U.S. Food and Drug Administration; c2018. Part 184. Direct food substances affirmed as generally recognized as safe. Sec 184.1097 Tannic acid; 2017 Aug 14 [cited 2018 Apr 18]; [about 1 screens] Available from: https://www.accessdata.fda.gov/scripts/cdrh/cfdocs/cfcfr/CFRSearch. $\mathrm{cfm}$ ?fr $=184.1097$.

51. Afsana K, Shiga K, Ishizuka S, Hara H. Reducing effect of ingesting tannic acid on the absorption of iron, but not of zinc, copper and manganese by rats. Biosci Biotechnol Biochem. 2004; 68(3): 584-92. [Medline] [CrossRef]

52. Tikoo K, Bhatt DK, Gaikwad AB, Sharma V, Kabra DG. Differential effects of tannic acid on cisplatin induced nephrotoxicity in rats. FEBS Lett. 2007; 581(10): 2027-35. [Medline] [CrossRef]

53. Boyd EM, Bereczky K, Godi I. The acute toxicity of tannic acid administered intragastrically. Can Med Assoc J. 1965; 92: 1292-7. [Medline]

54. Ha GE, Lee J, Kwak H, Song K, Kwon J, Jung SY, Hong J, Chang GE, Hwang EM, Shin HS, Lee CJ, Cheong E. The $\mathrm{Ca}^{2+}$-activated chloride channel anoctamin-2 mediates spike-frequency adaptation and regulates sensory transmission in thalamocortical neurons. Nat Commun. 2016; 7: 13791. [Medline] [CrossRef]

55. Savjani JK, Mulamkattil S, Variya B, Patel S. Molecular docking, synthesis and biological screening of mefenamic acid derivatives as anti-inflammatory agents. Eur J Pharmacol. 2017; 801: 28-34. [Medline] [CrossRef]

56. Zhang WY, Li Wan Po A. Efficacy of minor analgesics in primary dysmenorrhoea: a systematic review. Br J Obstet Gynaecol. 1998; 105(7): 780-9. [Medline] [CrossRef]

57. Al-Waili NS. Treatment of menstrual migraine with prostaglandin synthesis inhibitor mefenamic acid: double-blind study with placebo. Eur J Med Res. 2000; 5(4): 176-82. [Medline]

58. Pringsheim T, Davenport WJ, Dodick D. Acute treatment and prevention of menstrually related migraine headache: evidence-based review. Neurology. 2008; 70(17): 1555-63. [Medline] [CrossRef]

59. Mital P, Garg S, Khuteta RP, Khuteta S, Mital P. Mefenamic acid in prevention of premature labour. J R Soc Health. 1992; 112(5): 214-6. [Medline] [CrossRef]

60. Antonucci R, Zaffanello M, Puxeddu E, Porcella A, Cuzzolin L, Pilloni MD, Fanos V. Use of nonsteroidal anti-inflammatory drugs in pregnancy: impact on the fetus and newborn. Curr Drug Metab. 2012; 13(4): 474-90. [Medline] [CrossRef]

61. Kirilmis C, Ahmedzade M, Servi S, Koca M, Kizirgil A, Kazaz C. Synthesis and antimicrobial activity of some novel derivatives of benzofuran: part 2. The synthesis and antimicrobial activity of some novel 
1-(1-benzofuran-2-yl)-2-mesitylethanone derivatives. Eur J Med Chem. 2008; 43(2): 300-8. [Medline] [CrossRef]

62. Rindhe SS, Rode MA, Karale BK. New benzofuran derivatives as an antioxidant agent. Indian J Pharm Sci. 2010; 72(2): 231-5. [Medline] [CrossRef]

63. Stamp LK, O’Donnell JL, Chapman PT. Emerging therapies in the long-term management of hyperuricaemia and gout. Intern Med J. 2007; 37(4): 258-66. [Medline] [CrossRef]

64. Iwanaga T, Kobayashi D, Hirayama M, Maeda T, Tamai I. Involvement of uric acid transporter in increased renal clearance of the xanthine oxidase inhibitor oxypurinol induced by a uricosuric agent, benzbromarone. Drug Metab Dispos. 2005; 33(12): 1791-5. [Medline]

65. WHO Drug Information Vol 14, No. 1, 2000 [Internet]. Geneva: World Health Organization; c2000. Regulatory and Safety Matters, Benzbromarone and hepatitis; 2000 Mar 20 [cited 2018 Apr 18]; [about 2 screens] Available from: http://apps.who.int/medicinedocs/en/d/Jh1462e/7.11.html\#Jh1462e.7.11.

66. Lee MH, Graham GG, Williams KM, Day RO. A benefit-risk assessment of benzbromarone in the treatment of gout. Was its withdrawal from the market in the best interest of patients? Drug Saf. 2008; 31(8): 643-65. [Medline] [CrossRef]

67. Danielsson J, Perez-Zoghbi J, Bernstein K, Barajas MB, Zhang Y, Kumar S, Sharma PK, Gallos G, Emala CW. Antagonists of the TMEM16A calcium-activated chloride channel modulate airway smooth muscle tone and intracellular calcium. Anesthesiology. 2015; 123(3): 569-81. [Medline] [CrossRef] 